\title{
Does Size Matter?-The Effect of Size of Production Workers, Management Staff and Proprietors on Productivity
}

\author{
Awadhesh Pratap Singh \\ Indian Institute of Management, Lucknow, India \\ Email: awadheshp2000@gmail.com
}

How to cite this paper: Singh, A.P. (2018) Does Size Matter?-The Effect of Size of Production Workers, Management Staff and Proprietors on Productivity. Theoretical Economics Letters, 8, 2290-2307. https://doi.org/10.4236/tel.2018.811149

Received: May 17, 2018

Accepted: August 12, 2018

Published: August 15, 2018

Copyright $\odot 2018$ by author and Scientific Research Publishing Inc. This work is licensed under the Creative Commons Attribution International License (CC BY 4.0).

http://creativecommons.org/licenses/by/4.0/

\begin{abstract}
The importance of production workers is widely acknowledged in Industrial Economics. With respect to India where many industries are dominated by large family owned enterprises, this paper analyzes the impact of the size of production workers, management staff and proprietors on productivity for 11 manufacturing industries aggregated for 20 major states of India. The paper employs latest econometric techniques namely, panel cointegration and FMOLS that deals with widely known non-stationary and endogeneity issues in panel data. The results show that Indian manufacturing sector is highly sensitive to production workers and management staff. The externalities of production workers and management staff on TFP, output and labor productivity are consistently significant across the models. The significance to proprietors is found neither consistent nor significant.
\end{abstract}

\section{Keywords}

TFP, Labor Productivity, Output, FMOLS

\section{Introduction}

Many of us would agree with what a famous American Writer Mark Twain said a long ago: "it's not the size of the dog in the fight. It's the size of the fight in the dog that matters". In today's manufacturing world where it is important to focus on lean, self-organized teams, it is equally important to have a healthy ratio of production workers vs. management staff. At the same time, in the cultural context of India where many industries are dominated by large family owned enterprises, it would be interesting to know the role of proprietors to promote productivity.

This paper examines the role of production workers, supervisors and proprie- 
tors of the firm on total factor productivity (TFP), output and labor productivity for the 11 manufacturing industries aggregated for 20 major Indian states for the period 1998-2011. The paper uses advanced estimation techniques to estimate TFP and carry out estimations.

The goals of this paper are fourfold: First it calculates TFP using advanced estimation techniques to overcome problems of nonstationarity, omitted variables, endogeneity and reverse causality by applying panel FMOLS (fully modified OLS) estimator developed by Pedroni [1] [2] and panel cointegration test developed by Levin, Lin and Chu [3]. Second: It takes good care of data, measurement and variable issues which have generated good amount of debate in the past two decades (Kathuria et al. [4]). Third: It tried to find a relation between productivity and production workers, management staff and proprietors of the firms; fourth, it concludes the results and contributes towards productivity literature in the context of India.

The paper has been divided into 5 sections: In the first section, paper defines productivity and econometric issues surrounding it. The second section carries out a literature review in the context of production workers, management staff, proprietors and their impact to productivity. The third section shares the detail about data, variables and estimation methodology. The fourth section carries out detailed analysis and summarizes them. The fifth section concludes the findings and makes recommendations.

\section{Productivity: What Is It and How to Measure It?}

Economic growth relies on the use of production factors (labor and capital), its efficient usage and technical progress. How well the production factors are used is often referred as productivity (Kathuria et al. [4]). The economic growth leads to improvement in productivity and therefore higher standard of living (Balakrishnan and Pushpangadan [5]).

Production function is formulated with capital and labor as inputs and given below:

$$
\mathrm{Y}=\mathrm{A}+\mathrm{K}^{\alpha}+\mathrm{L}^{\beta}
$$

The above equation in Cobb-Douglas form represents total output $(\mathrm{Y})$ as a function of total-factor productivity (A), capital input (K), labor input (L), and the two inputs' respective shares of output ( $\alpha$ and $\beta$ are the share of contribution for $\mathrm{K}$ and $\mathrm{L}$ respectively). An increase in either $\mathrm{A}, \mathrm{K}$ or $\mathrm{L}$ will lead to an increase in output. Thus, total factor productivity refers to a variable which accounts for effects in total output growth relative to the growth in traditionally measured inputs. As such, its level is determined by how efficiently and intensely the inputs are utilized in production.

The level of TFP can be measured by dividing total output by total inputs (weighted average of labor and capital input). TFP growth is commonly referred as output growth less input growth.

Labor productivity (output/labor) is another way to measure productivity. This paper uses both the measures of productivity (TFP and labor productivity) 
to carry out analysis.

The measurement of TFP involves several issues such as: variable selection, measurement issues and methods selection. They are broadly termed as econometric issues and are briefly explained in the section below.

\section{Econometric Issues}

The issues related to variables selection arise as data to estimate TFP are not available in the suitable format. For every variables taken, there are numerous possible ways to treat the data and each of them are associated with certain degree of criticism (Srivastava and Sengupta, 2000; Kathuria et al., 2013). One of the prominent example is output measurement, which can be measured by either gross output or value added. The literature has demonstrated strong preference for using value-added as the measure of production (Goldar, [6], Goldar et al. [7], Kathuria et al. [4], Mitra et al. [8], Sharma et al. [9]). This paper uses value-added as output measurement.

Other issues related to variables selection include labor and capital measurements. Labor could be either measured by no. of hours spent versus total no. of workers employed. Many studies used the former one as it accounts for the partand full-time employees in terms of actual hours worked (Kathuria et al. [4]). This paper uses "number of persons engaged" retrieved from ASI (Annual Survey of Industries) as total employees for TFP computations. The approach iswidely accepted and is in line with the existing literature (Goldar [6], Goldar et al. [7], Sharma [10], Kathuria et al. [4], Singh [11]) in the context of ASI database.

With respect to capital series computation, it can be either measured as a stock measured by the book value of fixed assets or by the perpetual inventory method to construct capital stock series from annual investment data. This paper uses perpetual inventory method to build capital series which is widely used by previous researchers in the context of India (Goldar et al. [7], Sharma [10], Kathuria et al. [4], Singh [12]).

Measurement issues are often referred as single deflation (SD) and double deflation (DD). For the former one, nominal value-added and nominal material inputs both are deflated by the output price index. For the latter case, the nominal output is deflated by output price index and the nominal material inputs are by the input price index (Kathuria [4]). This paper uses double deflation which is highly recommended (Goldar [6], Sharma [10], Singh [12]).

\section{Production Workers, Management Staff, Proprietors and Productivity: Research}

Table 1 exhibits some of the important productivity studies in the context of managerial characteristics, ownership and production workers/skilled labors after 1990 .

Two key conclusions can be drawn from Table 1. First, the findings observed in these studies were largely mixed and slightly confusing. On one side Gort et al. 
Table 1. Key studies in the context of productivity, production workers, managerial characteristics and proprietors (ownership).

\begin{tabular}{|c|c|c|c|c|c|}
\hline$\underline{\text { Research (year) }}$ & $\underline{\text { Period }}$ & Country & Methodology & Objectives & Major Findings \\
\hline Curcio [25] & $1985-1990$ & UK & $\begin{array}{l}\text { Cobb Douglas } \\
\text { Production Function }\end{array}$ & $\begin{array}{l}\text { Investigates the relationship } \\
\text { between managerial ownership } \\
\text { and corporate performance }\end{array}$ & $\begin{array}{l}\text { Managerial ownership seems have a } \\
\text { positive effect on productivity growth; } \\
\text { however the estimates are not highly } \\
\text { significant. }\end{array}$ \\
\hline $\begin{array}{l}\text { Kahn, J. A., \& Lim, } \\
\text { J. S. [26] }\end{array}$ & 1958-1991 & United States & $\begin{array}{l}\text { Cobb Douglas } \\
\text { Production function } \\
\text { approach }\end{array}$ & $\begin{array}{l}\text { Examines the role of skilled } \\
\text { labor in TFP growth }\end{array}$ & $\begin{array}{l}\text { Robust evidences that productivity } \\
\text { growth was increasingly concentrated } \\
\text { in high-skill industries }\end{array}$ \\
\hline $\begin{array}{l}\text { Gort, Michael \& } \\
\text { Lee, S. H. [13] }\end{array}$ & $1973-92$ & United States & $\begin{array}{l}\text { Cobb Douglas } \\
\text { production function }\end{array}$ & $\begin{array}{l}\text { Analyzes the impact of } \\
\text { managerial efficiency on output }\end{array}$ & $\begin{array}{l}\text { Managerial endowments, superior } \\
\text { managerial efficiency is an important } \\
\text { explanatory variable for output }\end{array}$ \\
\hline $\begin{array}{l}\text { Amess, K. } \\
\text { \& Drakeb, L. [17] }\end{array}$ & 1991-1996 & UK & $\begin{array}{l}\text { Cobb Douglas } \\
\text { Production Function }\end{array}$ & $\begin{array}{l}\text { Relationship between the } \\
\text { remuneration of the highest } \\
\text { paid senior managers and } \\
\text { firm-level performance }\end{array}$ & $\begin{array}{l}\text { The relationship between pay and TFP } \\
\text { change is generally weak }\end{array}$ \\
\hline $\begin{array}{l}\text { Simoneti, M. \& } \\
\text { Gregoric, A. [18] }\end{array}$ & 1995-1999 & Slovenia & $\begin{array}{l}\text { Cobb Douglas } \\
\text { Production Function }\end{array}$ & $\begin{array}{l}\text { Investigates the influence of } \\
\text { managerial ownership on } \\
\text { performance of the firms. }\end{array}$ & $\begin{array}{l}\text { Do not provide relevant evidence of } \\
\text { any positive effects of the increasing } \\
\text { managerial control }\end{array}$ \\
\hline $\begin{array}{l}\text { Ilmakunnas, P.; } \\
\text { Maliranta, M.; } \\
\text { Vainiomäki, J. [20] }\end{array}$ & 1975-1994 & Finland & $\begin{array}{l}\text { Pooled OLS, random } \\
\text { effects and fixed } \\
\text { effects }\end{array}$ & $\begin{array}{l}\text { Analyzes the relationships of } \\
\text { worker characteristics such as } \\
\text { average age, seniority, and } \\
\text { education on productivity }\end{array}$ & $\begin{array}{l}\text { Plant average age and higher education } \\
\text { improves productivity }\end{array}$ \\
\hline $\begin{array}{c}\text { Fernandes, Ana M. } \\
{[14]}\end{array}$ & $\begin{array}{l}\text { November } \\
\text { 2004-Septemb } \\
\quad \text { er } 2005\end{array}$ & Bangladesh & $\mathrm{ACF}$ & $\begin{array}{l}\text { studies managerial quality and } \\
\text { its impact to firm's TFP }\end{array}$ & $\begin{array}{l}\text { Managerial quality and global } \\
\text { integration are positively associated } \\
\text { with firm TFP. }\end{array}$ \\
\hline Silva, A. C. [16] & $\begin{array}{l}\text { Empirical } \\
\text { Model }\end{array}$ & United States & $\begin{array}{l}\text { Cobb Douglas } \\
\text { production function } \\
\text { and model proposed } \\
\text { by Imrohoroglu and } \\
\text { Kumar (2004) }\end{array}$ & $\begin{array}{l}\text { Analyzes how managerial } \\
\text { ability—the ability to run risky } \\
\text { projects—can increase TFP }\end{array}$ & $\begin{array}{l}\text { Implies that countries with more } \\
\text { high-ability managers use more risky } \\
\text { projects and have higher productivity }\end{array}$ \\
\hline $\begin{array}{c}\text { Castellani, D \& } \\
\text { Giovannetti, G. [15] }\end{array}$ & $\begin{array}{l}1998-2000 \text { and } \\
2001-2003\end{array}$ & Italy & $\begin{array}{l}\text { OLS, OP, LP semi } \\
\text { parametric method } \\
\text { and fixed effects and } \\
\text { random Effects model }\end{array}$ & $\begin{array}{l}\text { Investigates whether higher use } \\
\text { of knowledge workers such as } \mathrm{R} \\
\& \mathrm{D} \text {, managerial and clerical } \\
\text { workers can explains some of } \\
\text { the TFP premium }\end{array}$ & $\begin{array}{l}\text { Managers complements in the } \\
\text { productivity of multinational firms }\end{array}$ \\
\hline $\begin{array}{l}\text { Majumdar, R.; Bala } \\
\text { Subrahmanya, M. } \\
\text { H. [27] }\end{array}$ & $1998-2008$ & India & $\begin{array}{l}\text { Cobb Douglas } \\
\text { Production Function }\end{array}$ & $\begin{array}{l}\text { Analyses the influence of } \\
\text { operational management } \\
\text { decisions on technical efficiency } \\
\text { (TE) and technological progress } \\
\text { (TP) and thus TFP }\end{array}$ & $\begin{array}{l}\text { The decision may impact TP but not } \\
\text { TE. Asset utilization, vertical } \\
\text { integration can improve } \mathrm{TP} \text { and } \mathrm{TE}\end{array}$ \\
\hline Unel, B. [23] & $1949-2005$ & United States & $\begin{array}{l}\text { Cobb Douglas } \\
\text { Production function } \\
\text { approach }\end{array}$ & $\begin{array}{l}\text { Analyzes time paths of the } \\
\text { efficiencies of skilled and } \\
\text { unskilled labor in a production } \\
\text { framework where skilled and } \\
\text { unskilled labor are imperfect } \\
\text { substitutes }\end{array}$ & $\begin{array}{l}\text { Although skilled labor efficiency has a } \\
\text { strong upward trend, no evidence was } \\
\text { found in its growth rate to accelerate } \\
\text { the new skilled-biased technologies }\end{array}$ \\
\hline
\end{tabular}




\section{Continued}

\begin{tabular}{|c|c|c|c|c|c|}
\hline Feyrer, J. [28] & $1960-2000$ & United States & $\begin{array}{l}\text { Cobb Douglas } \\
\text { Production Function }\end{array}$ & $\begin{array}{l}\text { Examines management changes } \\
\text { caused by the entry of the baby } \\
\text { boom, explain productivity } \\
\text { slowdown in 1970s and } \\
\text { resurgence in 1990s }\end{array}$ & $\begin{array}{l}\text { The management effects of the baby } \\
\text { boom may explain roughly } 20 \text { percent } \\
\text { of the observed productivity slowdown } \\
\text { and resurgence }\end{array}$ \\
\hline Sav, G. T. [19] & 2005-09 & United States & $\begin{array}{l}\text { DEA, Malmquist } \\
\text { index }\end{array}$ & $\begin{array}{l}\text { Investigate the extent to which } \\
\text { universities underwent } \\
\text { productivity change, due to } \\
\text { managerial performance }\end{array}$ & $\begin{array}{l}\text { Managerial efficiency tended to } \\
\text { hamper productivity gains but, on the } \\
\text { positive side, showed slight } \\
\text { improvements over time }\end{array}$ \\
\hline $\begin{array}{c}\text { Sharma, S.; } \\
\text { Singh, N. [29] }\end{array}$ & $\begin{array}{c}1973 / 74 \text { to } \\
2001 / 02\end{array}$ & India & system GMM & $\begin{array}{l}\text { Explores the impacts of skill } \\
\text { composition, the use of } \\
\text { imported intermediate inputs, } \\
\text { ownership and organizational } \\
\text { form on the productivity }\end{array}$ & $\begin{array}{l}\text { Finds some evidence } \\
\text { that access to financial capital, electric } \\
\text { power from the grid, and skilled } \\
\text { workers all matter }\end{array}$ \\
\hline $\begin{array}{l}\text { Baltagi, B. H., } \\
\text { Egger, P. H., \& } \\
\text { Kesina, M. [22] }\end{array}$ & 2004-2006 & China & $\begin{array}{l}\text { Cobb Douglas } \\
\text { Production function } \\
\text { approach, fixed } \\
\text { effects, random } \\
\text { effects }\end{array}$ & $\begin{array}{l}\text { Investigates intra-sectoral } \\
\text { spillovers in TFP and model } \\
\text { output by the firm as a function } \\
\text { of skilled and unskilled labor, } \\
\text { capital, materials, and TFP }\end{array}$ & $\begin{array}{l}\text { Finds evidence of positive spillovers } \\
\text { and a significant detrimental effect of } \\
\text { public ownership on TFP }\end{array}$ \\
\hline Alder, S. D. [24] & 1994-2010 & United States & $\begin{array}{l}\text { Cobb Douglas } \\
\text { Production Function, } \\
\text { Robert's law }\end{array}$ & $\begin{array}{l}\text { Explores managers as a source } \\
\text { of variation in aggregate output } \\
\text { and TFP }\end{array}$ & $\begin{array}{l}\text { Executive talent does not contribute to } \\
\text { the dispersion in US firm sizes and the } \\
\text { misallocation of talent has } \\
\text { inconsequential aggregate effects }\end{array}$ \\
\hline $\begin{array}{l}\text { Bloom, N. \& Sadun, } \\
\text { R. \& Van Reenen, J. } \\
\qquad[30]\end{array}$ & $\begin{array}{l}\text { Survey waves } \\
\text { in } 2004,2006, \\
2009 / 10,2013 \text {, } \\
\text { and } 2014\end{array}$ & 34 countries & $\begin{array}{l}\text { Surveys, Cobb } \\
\text { Douglas Production } \\
\text { Function, MAT } \\
\text { model }\end{array}$ & $\begin{array}{l}\text { Investigates whether } \\
\text { management practices akin to a } \\
\text { technology that can explain } \\
\text { company and national } \\
\text { productivity }\end{array}$ & $\begin{array}{l}\text { Differences in management practices } \\
\text { account for about } 30 \% \text { of } \\
\text { cross-country total factor productivity } \\
\text { differences. }\end{array}$ \\
\hline
\end{tabular}

[13], Fernandes [14] Castellani et al. [15] and Silva [16] were able to find links between managerial efficiency and productivity whereas on the other side Amess et al. [17], Simoneti [18], Sav [19] denied any such linksin their studies. Similarly, Ilmakunnas et al. [20], Sharma et al. [21], Baltagi et al. [22] observed positive externalities of production workers and their characteristics to productivity, however Unel [23] and Alder [24] could not observed the said relationships. In the same line and with respect to ownership, the findings observed by Curcio [25] and Baltagi et al. [22] contradicted each other. Unlike to old studies, this paper tries to revisit the relationship by taking three independent variables (production workers, management and proprietors) together and investigates their linkages with productivity.

Second, productivity estimates were carried out mostly by using traditional techniques such as OLS with less focus given on data treatment/validation such as nonstationarity, omitted variables, endogeneity and reverse causality. One such missis to employ the panel unit root test suggested by Pedroni [1] or Levin, Lin and Chu [3] that could lead to a commit a Type II error and may give biased results. This paper deals with these kinds of structural breaks and econometric 
issues by applying panel FMOLS (fully modified OLS) estimator developed by Pedroni [1] [2] and panel cointegration test developed by Levin, Lin and Chu [3].

In the light of the above findings, the objectives of this paper is to investigate the linkages between productivity and the size of production workers, size of management staff and the size of proprietors for 11 manufacturing industries aggregated for 20 major states of India.

\section{Data \& Variables}

ASI database (Annual Survey of Industries) is employed to collect the information of Indian manufacturing firms from 1998 to 2011. There are two reasons to take the data during this span. UPA (United Progressive Alliance) provided a stable regime in the country during this time period. Second, the data was readily available for this period in a uniform fashion. The sample covers 11 industries: Tobacco; Textiles; Apparel; Leather; Wood and Products of Wood; Paper and Paper Products; Manufacture of Coke, Refined Petroleum Products and Nuclear Fuel; Chemicals; Basic Metals; Machinery and Equipment and Motor Vehicles, Trailers and Semi-Trailers for 20 Major Indian States: Andra Pradesh, Assam, Uttar Pradesh, Gujrat, Madhya Pradesh, Tamil Nadu, West Bengal, Uttarakhand, Jharkhand, Chattisgadh, Jammu and Kashmir, Haryana, Himachal Pradesh, Kerala, Karnataka, Orissa, Punjab, Bihar, Rajasthan and Maharashtra.

The industries and states are picked up based on availability of data from the ASI database and their relevance to this paper (focused on manufacturing sector). The data series retrieved to carry out the analysis for this paper are: number of workers, number of employees, total persons engaged, fuel consumed, depreciation, gross value added, materials consumed and net fixed capital stock. An important fact to note here is ASI changed its industry classification two times during the period considered for this paper: firstly in 2003-04 and then subsequently in 2007-08. Therefore, to ensure the data sanctity and consistency, the 2 digits industries taken for this paper, have been compared, reclassified and rearranged appropriately. During this process, the industries that author could not compare and classify, have been taken out.

Real gross value series has been constructed by deflating the nominal data series by the wholesale price index for the manufacturing industries taken. 1998 has been taken as the base year.

Total number of persons engaged has been taken as the measure of labor input. This is consistent with the prior studies that employed ASI data (Kathuria [4]).

To build capital series, the author employed the method suggested by Krishna, Kapila [31]. The method employs net fixed capital stock at constant prices as the measure of capital inputs. The fixed capital stock series has been formulated by using perpetual inventory method. The 4 phased approach to formulate the fixed capital series is as follows: 1) by using the data on gross fixed capital formation 
in registered manufacturing at current and constants prices published by NAS (National Accounts Statistics), the implicit deflator for gross fixed capital formation is obtained. The deflator series is first formulated for 1979-1980 to 2010-2011. The base is then shifted to 1998-1999 to be consistent with the price series employed for intermediate inputs and outputs; 2) gross investment in fixed capital is calculated for each year by deducting the book value of fixed asset in the previous year from that in the current year and then adding to that figure the reported depreciation in fixed assets in the current year. Gross fixed investment for the years 1979-1980 to 1998-1999 was calculated from ASI data. To retrieve real gross investment, the nominal figures then were deflated using the implicit deflator for fixed investment as described above in the point 1 ; 3) The capital stock for base year (1998-1999) is calculated by first totaling the real fixed investment for different years during 1979-1980 to 1998-1999 and then provide adjustment for annual depreciation. Author considered 5\% as the rate of annual depreciation which is the same as assumed in the studies in Goldar [32] and mentioned by Singh [12]; 4) Starting from the fixed capital stock for 1998-1999 (benchmark) and then adding real net fixed investment for successive years, the net fixed capital stock series is formulated.

Real intermediate inputs have been taken as the sum of values of material, fuel and power. All these variables were expressed at constant prices of 1998-99. In order to obtain material inputs at constant prices, the series on material has been deflated. Author followed a common practice in the context of productivity studies conducted in India and constructed a material deflator by using input-output table.

The deflator is formed as a weighted average of price indices for various input-output sectors. For each sector, wholesale price indices have been employed. The input output table for 1993-94 published by CSO (Central Statistical Organization) has been used for this purpose. The columns in the absorption matrix for the 66 sectors belonging to manufacturing have been added together. The sum of the columns so obtained gives the purchases of materials made by manufacturing industries from various sectors, including supplied made by one industry to another as well as intraindustry transactions. This information is used to construct the weights (Krishna et al. [31]).

Energy inputs at constant prices have been obtained in the same manner it was done for materials. A price index for energy has been created by taking into account the expenses incurred by manufacturing industries on energy (petroleum products, coal and electricity) as published in the input-output table and by leveraging wholesale price indices for these three categories (petroleum products, coal and electricity) of energy inputs.

The comprehensive data cleaning was performed with the following stages 1) The study has taken only those industries into account for which data was available for the given years; 2) The data that reported zero or negative capital stock, zero output and zero persons engaged have been omitted 3) after the completion 
of steps 1 and 2, state-wise panels have been aggregated on industry levels to carry out analysis (Table 2).

\section{Estimating Total Factor Productivity}

The empirical analysis will be carried out by computing TFP of each industry. The paper follows a two steps technique. In the first step, a panel of 11 industries is created. Following Sharma et al. (2010), Cobb Douglas production function is written in the form as below:

$$
\mathrm{LY}_{i, t}=\alpha_{1} \mathrm{LK}_{i, t}+\alpha_{2} \mathrm{LN}_{i, t}+\alpha_{3} T_{i}+\varepsilon_{i t}
$$

Here $\mathrm{Y}, \mathrm{N}$ and $\mathrm{K}$ are, for each industry, value added, labor input and capital input respectively. $T_{\mathrm{i}}$ is the time trend specified for each industry $i$ taken into account and $\alpha_{1}, \alpha_{2}$ and $\alpha_{3}$ are the parameters that need to be estimated. $\varepsilon_{i t}$ is the error term that is also called disturbance term. The term $t$ denotes fixed time effects and $\mathrm{L}$ represents natural $\log$ of the variables.

To estimate the parameters, we carry out fixed-effects and random effects estimates using Stata software. Autocorrelation and heteroscedasticity could be the major issues that could impact productivity estimation. To overcome that Singh (2016) suggested to use robust error command that author also follows.

Table 2. Variables and their sources.

\begin{tabular}{|c|c|c|c|}
\hline Variable & Definition & Deflator & Data Source \\
\hline Output (Y) & $\begin{array}{l}\text { Gross value added (GVA) } \\
\text { to the firm }\end{array}$ & $\begin{array}{l}\text { Deflated by industry specific Wholesale } \\
\text { Price indices (WPI) }\end{array}$ & $\begin{array}{l}\text { 1) GVA obtained Annual Survey of Industries (EPW) } \\
\text { 2) WPI obtained from Office of the Economic Adviser } \\
\text { (OEA), the Ministry of Commerce \& Industry of India } \\
\text { (http://eaindustry.nic.in) }\end{array}$ \\
\hline Labor $(\mathrm{N})$ & Total persons engaged & - & $\begin{array}{l}\text { Total persons engaged obtained from Annual Survey of } \\
\text { Industries (EPW) }\end{array}$ \\
\hline Capital (K) & $\begin{array}{l}\text { Fixed capital stock series } \\
\text { constructed by perpetual } \\
\text { inventory method }\end{array}$ & $\begin{array}{l}\text { Deflator is derived from the data on gross } \\
\text { fixed capital formation in registered } \\
\text { manufacturing at current and constants } \\
\text { prices given in NAS }\end{array}$ & $\begin{array}{l}\text { 1) Net fixed capital formation obtained from Annual } \\
\text { Survey of Industries (EPW) } \\
\text { 2) Deflator obtained from Macroeconomic Aggregates } \\
\text { (https://data.gov.in) }\end{array}$ \\
\hline $\begin{array}{l}\text { Raw material, } \\
\text { power and fuel }\end{array}$ & $\begin{array}{l}\text { Real intermediate inputs } \\
\text { as sum of values of } \\
\text { material power and fuel }\end{array}$ & $\begin{array}{l}\text { Deflator formed as a weighted average of } \\
\text { price indices for various input-output } \\
\text { sectors }\end{array}$ & $\begin{array}{l}\text { 1) Net fixed capital formation obtained from Annual } \\
\text { Survey of Industries (EPW) } \\
\text { 2) Deflator formed as a weighted average of price indices } \\
\text { for various input-output sectors, Ministry of Statistics } \\
\text { and Program Implementation } \\
\text { (CSO-http://mospi.gov.in) }\end{array}$ \\
\hline $\begin{array}{l}\text { Production } \\
\text { workers to total } \\
\text { employees ratio }\end{array}$ & $\begin{array}{l}\text { Production workers } \\
\text { divided by total } \\
\text { employees }\end{array}$ & NA & $\begin{array}{l}\text { Production workers series is given as total workers in ASI } \\
\text { database }\end{array}$ \\
\hline $\begin{array}{l}\text { Management to } \\
\text { total employees } \\
\text { ratio }\end{array}$ & $\begin{array}{l}\text { Management staff divided } \\
\text { by total employees }\end{array}$ & NA & $\begin{array}{l}\text { Management staff is retrieved by subtracting total } \\
\text { workers from total employees in ASI database }\end{array}$ \\
\hline $\begin{array}{l}\text { Proprietors to } \\
\text { total employees } \\
\text { ratio }\end{array}$ & $\begin{array}{l}\text { Proprietors staff divided } \\
\text { by total employees }\end{array}$ & NA & $\begin{array}{l}\text { Proprietors staff is retrieved by subtracting total } \\
\text { employees from total persons engaged in ASI database }\end{array}$ \\
\hline
\end{tabular}


After estimating the fixed effects and random effects model, Hausman test confirms to use the fixed effects model. The result is presented in Table 3 that indicates that the output elasticities of labor and capital inputs as well as the constant are statistically significant at 5 percent $(P$ value -0.000$)$.

In the second stage, TFP of each industry will be computed by using the equation given below:

$$
\mathrm{TFP}_{i, t}=\mathrm{LY}_{i, t}-\hat{\alpha}_{1} \mathrm{LK}_{i, t}-\hat{\alpha}_{2} \mathrm{LN}_{i, t}
$$

Here $\hat{\alpha}_{1}$ and $\hat{\alpha}_{2}$ are the computed parameters of capital and labor, respectively.

The TFP computations are shown in Table 4 below. Three key conclusions can be drawn. First, the overall TFPs of the industries have improved for the period considered barring Tobacco industry. Two, Cock and Chemical products top the list across all three periods consistently. Third, Tobacco industry has been the laggard consistently across all three time periods.

\section{Estimating the Effect of Size of Production Workers, Management Staff, Proprietors on Productivity}

Our empirical model is based on the growth accounting framework where ratios

Table 3. Cobb Douglas estimation.

\begin{tabular}{cccc}
\hline Variables & Coefficients & t-statistics & $P$ value \\
\hline LK & 0.3981002 & 11.85 & 0.000 \\
LN & 1.120004 & 13.61 & 0.000 \\
Cons & -6.861463 & -5.40 & 0.000 \\
\hline
\end{tabular}

Notes: 1) The null hypothesis of Hausman test states that random effects model is appropriate; 2) The alternative hypothesis of Hausman test states that fixed effects model is appropriate.

Table 4. Average TPF growth of the industries for the period of 1998-2011.

\begin{tabular}{cccc}
\hline Industry & $\begin{array}{c}\text { Average TFP } \\
(1998-2004)\end{array}$ & $\begin{array}{c}\text { Average TFP } \\
(2005-2011)\end{array}$ & $\begin{array}{c}\text { Average TFP } \\
(1998-2011)\end{array}$ \\
\hline 16 Tobacco & 1.280019 & 1.173772 & 1.211896 \\
17 Textiles & 1.393035 & 1.413747 & 1.338391 \\
18 Apparel & 1.397534 & 1.446872 & 1.422203 \\
19 Leather products & 1.589003 & 1.593607 & 1.556305 \\
20 Woodland products & 1.335713 & 1.500786 & 1.418249 \\
21 Paper products & 1.444310 & 1.613291 & 1.528801 \\
23 Coke/petroleum products & 3.209535 & 3.876863 & 3.543199 \\
24 Chemical products & 2.449141 & 2.729833 & 2.379487 \\
25 Rubber \& plastics products & 1.596164 & 1.849237 & 1.672700 \\
27 Basic metals & 1.809127 & 2.080311 & 1.944719 \\
29 Machinery \& equipment & 1.425758 & 2.055246 & 1.740502 \\
34 Motor vehicles, trailers \& semi-trailers & 1.573079 & 2.039230 & 1.806155 \\
\hline
\end{tabular}

Notes: The TFP has been averaged out across three time periods-1) 1998-2004 2) 2005-2011 and 3) 1998-2011. 
of production workers, management staff and proprietors to the total employees are modelled as the function of productivity.

Our empirical models to be estimated are as follows

Model 1: $\mathrm{TFP}_{i, t}=\alpha+\gamma \mathrm{LPW}_{i, t}+u_{i t}$

Model 2: $\operatorname{TFP}_{i, t}=\alpha+\gamma \mathrm{LMS}_{i, t}+u_{i t}$

Model 3: $\operatorname{TFP}_{i, t}=\alpha+\gamma \operatorname{LPS}_{i, t}+u_{i t}$

Model 4: $\mathrm{TFP}_{i, t}=\alpha+\gamma_{1} \mathrm{LPW}_{i, t}+\gamma_{2} \mathrm{LMS}_{i, t}+\gamma_{3} \mathrm{LPS}_{i, t}+u_{i t}$

Model 5: $\quad \mathrm{TFP}_{i, t}=\alpha+\beta_{1} \mathrm{LK}_{i, t}+\beta_{2} \mathrm{LN}_{i, t}+\gamma_{1} \mathrm{LPW}_{i, t}+\gamma_{2} \mathrm{LMS}_{i, t}+\gamma_{3} \mathrm{LPS}_{i, t}+u_{i t}$

Here $\mathrm{TFP}_{i, t}$ is TFP of the industry $i$ for the period $t$ whereas PW is the production workers to total employees ratio, MS is the management to total employees ratio and PS is the proprietors to total employees ratio. $\mathrm{L}$ indicates that variable is in logarithm form. The parameters that need to be estimated are $\beta$ and $\gamma$. Model 1, 2 and 3 estimate the impact of production workers, management staff and proprietors, respectively on TFP of industries. Model 4 aggregates model 1, 2 and 3 to compute the combined impact of these variables to productivity. Model 5 includes industry specific factors such as labor and capital and sums them up with model 4.

Further, we will also test the impact on output and labor productivity (output/number of workers) from the below models

Model 6: $\operatorname{LGVA}_{i, t}=\alpha+\gamma_{1} \mathrm{LPW}_{i, t}+\gamma_{2} \mathrm{LMS}_{i, t}+\gamma_{3} \mathrm{LPS}_{i, t}+u_{i t}$

Model 7: $\operatorname{LLP}_{i, t}=\alpha+\gamma_{1} \mathrm{LPW}_{i, t}+\gamma_{2} \mathrm{LMS}_{i, t}+\gamma_{3} \mathrm{LPS}_{i, t}+u_{i t}$

Here GVA refers to gross value added and LP indicates labor productivity. The prefix $\mathrm{L}$ indicates that the variables are in their logarithm form.

\subsection{Econometrics Issues-Stationarity and Cointegration}

As non-stationarity of data series causes serious estimation issues, this paper utilizes unit root test and cointegration techniques to deal with the integrating relationships among the variables in the panel context. To test unit root, this study uses Levin-Lin-Chu test that assumes a common autoregressive parameter for all panels and involves fitting an augmented Dickey-Fuller regression for each panel. The biggest advantage of this technique is that it deals with impending crosssectional dependencies and does not pool directly the autoregressive parameter in the unit root regression (Sharma et al., 2010).

The outcome of Levin-Lin-Chu test is reported in Table 5. The result clearly states that for all individual series the hypothesis of unit root cannot be rejected, however it is rejected at their first differences.

If the data series is found to have panel unit roots, it is then important to examine the panel cointegration. In this context, the paper applies Levin, Lin and Chu (2002) test-an enhancement of Pedroni's (1999) test and an extension of Engle-Granger technique to evaluate cointengration relationship. We use this test due to the reason that panel unit root tests are much more robust (less likely to commit a Type II error) than the unit root tests applied to individual series because the information in the time series is improved by that contained in the cross-section data. 
Table 5. Levin-Lin-Chu panel unit-root test.

\begin{tabular}{ccc}
\hline Variables & At level & At first difference \\
\hline TFP & $-1.7102^{\star}$ & $-3.97821^{\star}$ \\
LPW & 2.2464 & $-2.12068^{\star}$ \\
LMS & 4.0039 & $-1.97001^{\star}$ \\
LPS & $-3.6849^{\star}$ & $-4.97001^{\star}$ \\
LGVA & 1.3842 & $-2.12933^{\star}$ \\
LLP & 1.2912 & $-3.11822^{\star}$ \\
LK & -0.6335 & $-1.93771^{\star}$ \\
LN & 2.7500 & $-1.93771^{\star} \mathrm{t}$ \\
\hline
\end{tabular}

Notes: 1$){ }^{*}$ represents significance at $5 \%$ level; 2 ) $t$ indicates inclusion of trend.

Like Pedroni (1999), Levin, Lin and Chu formulated two kinds of tests-1). Withindimension and 2). Between-dimension approach. This paper uses both heterogeneous panelcointegration and heterogeneous group mean panel cointegration statistics-the results of which are presented in Table 6. The rows categorized within-dimension technique comprises formulated value of the statistics built on the estimators that pools the autoregressive coefficient for the industries taken by us for the unit root tests on estimated residuals. The rows categorized between-dimension presents the calculated value of the statistics built on estimators that averages individually estimated coefficients for each industry taken by us. Finally, these results help to validate the cointegrating relationship for all our models which conclude that the variables are in our model have long run association.

After recognizing that there is a linear grouping among variables that retains the pooled variables in ratio to one another for a long run, we can now compute individual long-run estimates for all our models.

Apparently OLS technique for our cointegrated panels may give biased results and would be unreliable (Sharma [10], Singh [33]). Instead we use FMOLS estimation technique suggested by Pedroni ([1] [2]).

\subsection{Estimation Outcome}

To estimate the models, group-mean FMOLS has been chosen. It is because of the reason that the sample taken after aggregation (aggregated on industry level for 20 states) is relatively smaller. Pedroni [1] [2] demonstrated that groupFMOLS has relatively lower sample alternations with more reliability compared to other three versions of FMOLS (Sharma [10]).

Tables 7-9 represent the results of all our models. The results of model 1, 2 and 3 are presented in Table 7 . The outcome indicates that the impact of production workers, management staff and proprietors on TFP is significant. Out of 11 industries, the elasticity for production workers was significant for 11 cases. The elasticities for management staff and proprietors were significant for 10 
Table 6. Panel cointegration test of Levin, Lin and Chu (2002).

\begin{tabular}{|c|c|c|c|c|c|c|c|}
\hline Industry & $\begin{array}{c}\text { Model } 1 \\
\text { TFP, LPW }\end{array}$ & $\begin{array}{c}\text { Model } 2 \\
\text { TFP, LMS }\end{array}$ & $\begin{array}{l}\text { Model } 3 \\
\text { TFP, LPS }\end{array}$ & $\begin{array}{c}\text { Model } 4 \\
\text { TFP, LPW } \\
\text { LMS, LPS }\end{array}$ & $\begin{array}{c}\text { Model } 5 \\
\text { TFP, LN, LK, } \\
\text { LPW, LMS, LPS }\end{array}$ & $\begin{array}{c}\text { Model } 6 \\
\text { LGVA, LPW } \\
\text { LMS, LPS }\end{array}$ & $\begin{array}{c}\text { Model } 7 \\
\text { LLP, LPW } \\
\text { LMS, LPS }\end{array}$ \\
\hline \multicolumn{8}{|c|}{ Within dimension } \\
\hline Panel $v$-statistic & $0.130156^{*}$ & $-0.8027^{\star}$ & $-1.1212^{*}$ & $-0.7344^{\star}$ & $-1.06218^{\star}$ & $-1.2439^{\star}$ & $-1.24526^{*}$ \\
\hline Panel $\rho$-statistic & -2.26606 & $-0.4921^{\star}$ & $-0.1042^{\star}$ & $0.776996^{*}$ & $2.398935^{\star}$ & $1.506255^{\star}$ & $1.54915^{*}$ \\
\hline Panel PP-statistic & -6.1655 & -3.50799 & -2.29071 & -2.9479 & -4.64576 & $-1.39032^{\star *}$ & $-1.38424^{* *}$ \\
\hline Panel ADF-statistic & -4.56598 & -3.7262 & -1.93872 & -3.20042 & -4.09079 & $-1.56032^{\star \star}$ & $-1.57249^{* *}$ \\
\hline \multicolumn{8}{|c|}{ Between dimension } \\
\hline Panel $\rho$-statistic & -1.14839 & $-0.5170^{\star}$ & $0.40412^{*}$ & $2.18384^{\star}$ & $4.455853^{\star}$ & $2.12616^{*}$ & $2.179428^{\star}$ \\
\hline Panel PP-statistic & -8.97413 & -6.42474 & -3.75229 & -8.00069 & -8.62577 & -6.82544 & -6.69809 \\
\hline Panel ADF-statistic & -6.53083 & -6.3997 & -2.26496 & -5.08535 & -4.88383 & -4.75467 & -4.77406 \\
\hline
\end{tabular}

Notes: 1$)^{*}$ represents significance at 5 percent; 2$)^{* *}$ indicates significance at 10 percent.

Table 7. Impact of production workers, management staff and proprietors on total factor productivity.

\begin{tabular}{ccccccc}
\hline \multirow{2}{*}{ Industry } & \multicolumn{2}{c}{ Model 1 } & \multicolumn{2}{c}{ Model 2 } & \multicolumn{2}{c}{ Model 3 } \\
& \multicolumn{2}{c}{ TFP, LPW } & \multicolumn{2}{c}{ TFP, LMS } & \multicolumn{2}{c}{ TFP, LPS } \\
\hline & Coefficients & t-stats & Coefficients & t-stats & Coefficients & t-stats \\
\hline 16 Tobacco & $0.06^{*}$ & 101.08 & $0.02^{*}$ & 69.13 & $0.03^{*}$ & 45.76 \\
17 Textiles & $0.06^{*}$ & 32.76 & $0.06^{*}$ & 23.87 & $0.07^{*}$ & 26.64 \\
18 Apparel & $0.07^{*}$ & 36.22 & $0.08^{*}$ & 37.52 & $0.08^{*}$ & 38.24 \\
19 Leather products & $0.08^{*}$ & 36.74 & $0.09^{*}$ & 33.05 & $0.10^{*}$ & 36.29 \\
20 Woodland products & $0.08^{*}$ & 32.26 & $0.09^{*}$ & 30.86 & $0.10^{*}$ & 28.01 \\
21 Paper products & $0.08^{*}$ & 44.23 & $0.08^{*}$ & 71.46 & $0.09^{*}$ & 41.34 \\
23 Coke/petroleum \\
products
\end{tabular}

Notes: 1$)^{\star}$ represents significance at 5 percent; 2 ) ${ }^{\star *}$ indicates significance at 10 percent.

industries. For the overall manufacturing sector, the elasticities reported for production workers, management staff and proprietors are 0.089, 0.098 and 0.11 (last row) respectively and they are sufficiently large. This finding will encourage the belief of those who believe that besides production workers, management staff and proprietors also promote growth. Surprisingly, the analysis fails to 
Table 8. Impact of production workers, management staff and proprietors on total factor productivity.

\begin{tabular}{|c|c|c|c|c|c|c|c|c|}
\hline \multirow[t]{2}{*}{ Industry } & \multicolumn{3}{|c|}{$\begin{array}{c}\text { Model } 4 \\
\text { (Dependent variable TFP) }\end{array}$} & \multicolumn{5}{|c|}{$\begin{array}{c}\text { Model 5 } \\
\text { (Dependent variable TFP) }\end{array}$} \\
\hline & LPW & LMS & LPS & $\mathrm{LN}$ & LK & LPW & LMS & LPS \\
\hline 16 Tobacco & $\begin{array}{l}0.003 \\
(0.02)\end{array}$ & $\begin{array}{c}-0.08 \\
(-2.30)^{*}\end{array}$ & $\begin{array}{c}0.15 \\
(1.08)\end{array}$ & $\begin{array}{c}-40.95 \\
(-1.98)^{\star *}\end{array}$ & $\begin{array}{c}0.02 \\
(0.70)\end{array}$ & $\begin{array}{c}9.61 \\
(1.98)^{* *}\end{array}$ & $\begin{array}{c}1.56 \\
(2.08)^{\star *}\end{array}$ & $\begin{array}{c}0.19 \\
(1.22)\end{array}$ \\
\hline 17 Textiles & $\begin{array}{c}0.13 \\
(0.68)\end{array}$ & $\begin{array}{c}-0.90 \\
(-2.12)^{*}\end{array}$ & $\begin{array}{c}0.02 \\
(0.13)\end{array}$ & $\begin{array}{l}-0.11 \\
(1.99)^{\star \star}\end{array}$ & $\begin{array}{c}3.82 \\
(-1.49)\end{array}$ & $\begin{array}{l}-2.17 \\
(-1.49)\end{array}$ & $\begin{array}{c}-0.13 \\
(1.89) * *\end{array}$ & $\begin{array}{l}-0.18 \\
(-1.49)\end{array}$ \\
\hline 18 Apparel & $\begin{array}{c}-0.43 \\
(-2.10)^{\star}\end{array}$ & $\begin{array}{c}0.30 \\
(1.58)\end{array}$ & $\begin{array}{c}0.28 \\
(3.47)^{\star}\end{array}$ & $\begin{array}{l}-4.30 \\
(-1.17)\end{array}$ & $\begin{array}{c}-0.44 \\
(-2.51)^{\star}\end{array}$ & $\begin{array}{c}0.22 \\
(3.15)^{*}\end{array}$ & $\begin{array}{c}0.98 \\
(3.14)^{\star}\end{array}$ & $\begin{array}{c}3.89 \\
(1.09)\end{array}$ \\
\hline 19 Leather products & $\begin{array}{c}0.23 \\
(0.77)\end{array}$ & $\begin{array}{c}0.20 \\
(2.19)^{*}\end{array}$ & $\begin{array}{l}-0.35 \\
(-1.06)\end{array}$ & $\begin{array}{l}-16.33 \\
(-2.60)^{*}\end{array}$ & $\begin{array}{c}-0.68 \\
(-3.78)^{*}\end{array}$ & $\begin{array}{c}5.49 \\
(2.69)^{*}\end{array}$ & $\begin{array}{c}2.00 \\
(2.39)^{*}\end{array}$ & $\begin{array}{c}0.15 \\
(1.16)^{*}\end{array}$ \\
\hline 20 Woodland products & $\begin{array}{c}0.70 \\
(1.98)^{*}\end{array}$ & $\begin{array}{c}-0.07 \\
(-0.40)\end{array}$ & $\begin{array}{c}-0.06 \\
(-0.71)\end{array}$ & $\begin{array}{l}-15.74 \\
(-3.05)^{\star}\end{array}$ & $\begin{array}{c}-0.12 \\
(-1.40)\end{array}$ & $\begin{array}{c}13.57 \\
(3.05)^{\star}\end{array}$ & $\begin{array}{c}2.43 \\
(3.04)^{\star}\end{array}$ & $\begin{array}{c}0.49 \\
(2.45)^{*}\end{array}$ \\
\hline 21 Paper products & $\begin{array}{c}1.10 \\
(1.90)^{*}\end{array}$ & $\begin{array}{c}-0.19 \\
(-2.98)^{*}\end{array}$ & $\begin{array}{c}0.09 \\
(0.34)\end{array}$ & $\begin{array}{l}-3.15 \\
(-0.52)\end{array}$ & $\begin{array}{c}0.17 \\
(1.91)^{\star}\end{array}$ & $\begin{array}{c}2.28 \\
(0.47)\end{array}$ & $\begin{array}{c}0.83 \\
(0.70)\end{array}$ & $\begin{array}{l}-0.02 \\
(-0.09)\end{array}$ \\
\hline $\begin{array}{l}23 \text { Coke/petroleum } \\
\text { products }\end{array}$ & $\begin{array}{c}1.99 \\
(3.06)^{*}\end{array}$ & $\begin{array}{c}2.10 \\
(3.18)^{*}\end{array}$ & $\begin{array}{c}0.20 \\
(1.09)\end{array}$ & $\begin{array}{c}8.42 \\
(0.79)\end{array}$ & $\begin{array}{c}0.31 \\
(3.39)^{\star}\end{array}$ & $\begin{array}{c}5.68 \\
(0.69)\end{array}$ & $\begin{array}{l}-3.15 \\
(-1.21)\end{array}$ & $\begin{array}{l}-0.25 \\
(-0.55)\end{array}$ \\
\hline 24 Chemical products & $\begin{array}{c}1.09 \\
(0.1 .93)^{\star}\end{array}$ & $\begin{array}{l}1.28 \\
(0.64)\end{array}$ & $\begin{array}{c}0.18 \\
(0.70)\end{array}$ & $\begin{array}{l}-5.96 \\
(-1.09)\end{array}$ & $\begin{array}{l}-0.37^{\star} \\
(-9.182)\end{array}$ & $\begin{array}{c}3.61 \\
(1.88)^{\star}\end{array}$ & $\begin{array}{c}0.63 \\
(5.41)^{\star}\end{array}$ & $\begin{array}{l}-0.11 \\
(-0.66)\end{array}$ \\
\hline 27 Basic metals & $\begin{array}{c}0.38 \\
(1.55)^{\star *}\end{array}$ & $\begin{array}{l}-0.29 \\
(-1.09)\end{array}$ & $\begin{array}{l}-0.02 \\
(-0.18)\end{array}$ & $\begin{array}{c}-10.81 \\
(-4.28)^{\star}\end{array}$ & $\begin{array}{c}0.17 \\
(1.34)\end{array}$ & $\begin{array}{c}8.49 \\
(4.22)^{*}\end{array}$ & $\begin{array}{c}1.90 \\
(2.98)^{*}\end{array}$ & $\begin{array}{c}-0.42 \\
(-0.38)\end{array}$ \\
\hline $\begin{array}{l}29 \text { Machinery \& } \\
\text { equipment }\end{array}$ & $\begin{array}{c}0.22 \\
(1.87)^{\star}\end{array}$ & $\begin{array}{c}-0.52 \\
(-1.85)^{\star}\end{array}$ & $\begin{array}{c}-0.57 \\
(-1.17)\end{array}$ & $\begin{array}{l}-21.64 \\
(-1.15)\end{array}$ & $\begin{array}{l}-0.09 \\
(-0.09)\end{array}$ & $\begin{array}{l}15.89 \\
(1.36)\end{array}$ & $\begin{array}{c}5.97 \\
(1.05)\end{array}$ & $\begin{array}{c}0.82 \\
(0.69)\end{array}$ \\
\hline $\begin{array}{l}34 \text { Motor vehicles, trailers } \\
\text { \& semi-trailers }\end{array}$ & $\begin{array}{c}2.13 \\
(6.37)^{\star}\end{array}$ & $\begin{array}{c}-1.80 \\
(-5.57)^{\star}\end{array}$ & $\begin{array}{c}-0.42 \\
(-4.00)^{*}\end{array}$ & $\begin{array}{c}9.31 \\
(1.15)\end{array}$ & $\begin{array}{c}-0.75 \\
(-1.76)^{*}\end{array}$ & $\begin{array}{c}-0.78 \\
(-2.43)^{*}\end{array}$ & $\begin{array}{c}-3.87 \\
(-1.91)^{*}\end{array}$ & $\begin{array}{l}-4.03 \\
(-0.73)\end{array}$ \\
\hline Overall & $\begin{array}{c}0.19 \\
(1.70)^{*}\end{array}$ & $\begin{array}{c}0.18 \\
(1.81)^{\star}\end{array}$ & $\begin{array}{c}0.10 \\
(0.57)\end{array}$ & $\begin{array}{c}4.18 \\
(2.43)^{\star}\end{array}$ & $\begin{array}{c}0.31 \\
(6.29)^{\star}\end{array}$ & $\begin{array}{c}0.67 \\
(2.54205)^{*}\end{array}$ & $\begin{array}{c}0.09 \\
(2.73)^{*}\end{array}$ & $\begin{array}{c}-0.09 \\
(-0.71)\end{array}$ \\
\hline
\end{tabular}

Notes: $1{ }^{*}$ represents significance at 5 percent; 2$)^{* *}$ indicates significance at 10 percent.

establish any impact incurred from the externalities of management staff and proprietors on TFP for Tobacco industry. Though the elasticity of production workers is significant in this case. The FMOLS estimates also present the results for each of the industry. The TFP of Petroleum product and Chemical industry is most sensitive with respect to production workers, management staff and proprietors. Interestingly, the elasticities of both the industries are higher than the manufacturing sector as a whole. The elasticity for management staff is higher than the overall manufacturing sector for Basic Metal.

Our analysis is extended for model 4 and 5 for TFP using FMOLS and results are presented in Table 8. Outcome of model 4 indicates that overall computed elasticities of TFP with respect to production workers, management staff are 0.19 and 0.18 respectively and the values are sufficiently large. Though the analysis fails to establish any impact incurred from the externalities of proprietors on TFP. The industry-wise estimation yields result similar to that of overall manufacturing sector for model 4. It suggests that production workers have significant impact on eight of the eleven industries in our sample. Similarly, management staff has significant impact on seven of the eleven industries in our sample. TFPs are not influenced by the externalities of proprietors for majority of the 
Table 9. Impact of production workers, management staff and proprietors on output and labor productivity.

\begin{tabular}{|c|c|c|c|c|c|c|}
\hline \multirow[t]{2}{*}{ Industry } & \multicolumn{3}{|c|}{$\begin{array}{c}\text { Model 6 } \\
\text { (Dependent variable LGVA) }\end{array}$} & \multicolumn{3}{|c|}{$\begin{array}{c}\text { Model } 7 \\
\text { (Dependent variable LLP) }\end{array}$} \\
\hline & LPW & LMS & LMS & LPW & LMS & LPS \\
\hline 16 Tobacco & $\begin{array}{c}1.95 \\
(3.68)^{*}\end{array}$ & $\begin{array}{l}-0.33 \\
(-0.52)\end{array}$ & $\begin{array}{l}-0.60 \\
(-3.50)^{\star}\end{array}$ & $\begin{array}{c}0.98 \\
(1.85)^{* *}\end{array}$ & $\begin{array}{l}-0.36 \\
(-0.57)\end{array}$ & $\begin{array}{c}-0.61 \\
(-3.54)^{*}\end{array}$ \\
\hline 17 Textiles & $\begin{array}{c}2.43 \\
(4.71)^{*}\end{array}$ & $\begin{array}{l}-1.20 \\
(-2.66)^{*}\end{array}$ & $\begin{array}{l}-0.02 \\
(-0.15)\end{array}$ & $\begin{array}{c}1.70 \\
(3.26)^{*}\end{array}$ & $\begin{array}{c}-1.47 \\
(-3.25)^{*}\end{array}$ & $\begin{array}{l}-0.05 \\
(-0.30)\end{array}$ \\
\hline 18 Apparel & $\begin{array}{c}0.44 \\
(2.50)^{*}\end{array}$ & $\begin{array}{c}0.70 \\
(4.18)^{*}\end{array}$ & $\begin{array}{c}0.20 \\
(2.86)^{*}\end{array}$ & $\begin{array}{c}-0.51 \\
(-2.79)^{*}\end{array}$ & $\begin{array}{c}0.66 \\
(3.86)^{*}\end{array}$ & $\begin{array}{c}0.19 \\
(2.63)^{*}\end{array}$ \\
\hline 19 Leather products & $\begin{array}{c}1.26 \\
(3.15)^{\star}\end{array}$ & $\begin{array}{c}0.18 \\
(0.42)\end{array}$ & $\begin{array}{c}-0.20 \\
(-1.63)\end{array}$ & $\begin{array}{c}0.37 \\
(0.88)\end{array}$ & $\begin{array}{c}0.08 \\
(0.18)\end{array}$ & $\begin{array}{c}-0.24 \\
(-1.84)^{\star \star}\end{array}$ \\
\hline $\begin{array}{l}20 \text { Woodland } \\
\text { products }\end{array}$ & $\begin{array}{c}1.49 \\
(3.24)^{*}\end{array}$ & $\begin{array}{l}-0.28 \\
(-0.54)\end{array}$ & $\begin{array}{c}0.06 \\
(0.24)\end{array}$ & $\begin{array}{c}0.65 \\
(1.38)\end{array}$ & $\begin{array}{l}-0.44 \\
(-0.84)\end{array}$ & $\begin{array}{c}0.03 \\
(0.11)\end{array}$ \\
\hline 21 Paper products & $\begin{array}{c}1.69 \\
(3.18)\end{array}$ & $\begin{array}{l}-0.13 \\
(-0.26)\end{array}$ & $\begin{array}{l}-0.30 \\
(-2.35)\end{array}$ & $\begin{array}{c}0.89 \\
(1.68)^{* *}\end{array}$ & $\begin{array}{l}-0.33 \\
(-0.63)\end{array}$ & $\begin{array}{c}-0.34 \\
(-2.62)^{*}\end{array}$ \\
\hline $\begin{array}{l}23 \text { Coke/petroleum } \\
\text { products }\end{array}$ & $\begin{array}{c}4.13 \\
(3.83)^{*}\end{array}$ & $\begin{array}{c}3.19 \\
(2.91)^{*}\end{array}$ & $\begin{array}{c}0.39 \\
(1.26)\end{array}$ & $\begin{array}{c}3.38 \\
(3.11)^{*}\end{array}$ & $\begin{array}{c}3.43 \\
(3.12)^{*}\end{array}$ & $\begin{array}{c}0.35 \\
(1.13)\end{array}$ \\
\hline $\begin{array}{l}24 \text { Chemical } \\
\text { products }\end{array}$ & $\begin{array}{c}3.42 \\
(16.75)^{*}\end{array}$ & $\begin{array}{c}1.86 \\
(9.50)^{*}\end{array}$ & $\begin{array}{c}-0.35 \\
(-2.98)^{*}\end{array}$ & $\begin{array}{c}2.64 \\
(12.63)^{*}\end{array}$ & $\begin{array}{c}2.08 \\
(10.37)^{\star}\end{array}$ & $\begin{array}{c}-0.38 \\
(-3.19)^{*}\end{array}$ \\
\hline 27 Basic metals & $\begin{array}{c}1.31 \\
(3.63)^{*}\end{array}$ & $\begin{array}{c}0.14 \\
(0.36)\end{array}$ & $\begin{array}{l}-0.14 \\
(-0.83)\end{array}$ & $\begin{array}{c}0.55 \\
(1.47)\end{array}$ & $\begin{array}{l}-0.07 \\
(-0.19)\end{array}$ & $\begin{array}{l}-0.20 \\
(-1.09)\end{array}$ \\
\hline $\begin{array}{c}29 \text { Machinery \& } \\
\text { equipment }\end{array}$ & $\begin{array}{c}2.13 \\
(4.36)^{*}\end{array}$ & $\begin{array}{l}-0.40 \\
(-0.99)\end{array}$ & $\begin{array}{c}-0.48 \\
(-2.01)^{*}\end{array}$ & $\begin{array}{c}1.49 \\
(3.00)^{*}\end{array}$ & $\begin{array}{c}-0.74 \\
(-1.78)^{*}\end{array}$ & $\begin{array}{c}-0.54 \\
(-2.26)^{*}\end{array}$ \\
\hline $\begin{array}{l}34 \text { Motor vehicles, } \\
\text { trailers \& } \\
\text { semi-trailers }\end{array}$ & $\begin{array}{c}2.76 \\
(8.47)^{\star}\end{array}$ & $\begin{array}{c}-1.176 \\
(-3.72)^{\star}\end{array}$ & $\begin{array}{c}-0.39 \\
(-3.87)^{\star}\end{array}$ & $\begin{array}{c}2.07 \\
(6.44)^{*}\end{array}$ & $\begin{array}{c}-1.48 \\
(-4.76)^{*}\end{array}$ & $\begin{array}{c}-0.43 \\
(-4.32)^{\star}\end{array}$ \\
\hline Overall & $\begin{array}{c}0.37 \\
(1.97)^{\star}\end{array}$ & $\begin{array}{c}0.11 \\
(2.71)^{\star}\end{array}$ & $\begin{array}{c}0.24 \\
(0.89)\end{array}$ & $\begin{array}{c}0.15 \\
(2.95)^{\star}\end{array}$ & $\begin{array}{c}0.26 \\
(2.34)^{\star}\end{array}$ & $\begin{array}{c}0.21 \\
(0.80)\end{array}$ \\
\hline
\end{tabular}

Notes: 1$)^{*}$ represents significance at 5 percent; 2$){ }^{* *}$ indicates significance at 10 percent.

industries in our sample barring Apparel and Motor Vehicles. The overall elasticity of TFP is 0.18 and 0.19 for production workers and management staff respectively which shows a significant improvement from model 1 and 2 . This is sufficiently large and indicates that 1 percent increase in production workers and management staff is associated with a 0.18 percent and 0.19 percent increase in TFP respectively.

The outcome of model 5 follows the similar line of model 1, 2 and 4. Here, overall elasticity of TFP is recorded as 0.67 and 0.09 for production workers and management staff respectively. Comparing to model 4 , while this shows a significant improvement for production workers, it also shows a drop in the externalities for management staff. However in both the cases, the model is quite consistent with respect to production workers and management staff and confirms both of them are statistically significant to explain the impact on TFP. Proprietors is not found to be significant in this case the industry-wise estimation for model 5 yields results similar to that of overall manufacturing sector for model 
4. It suggests that production workers have significant impact on seven of the eleven industries in our sample. Similarly, management staff has significant impact on eight of the eleven industries in our sample. TFPs are not influenced by the externalities of proprietors for majority of the industries in our sample barring Leather and Woodland products

Table 9 shows the outcome of model 6 and 7. Model 6 shows overall elasticity of TFP is recorded as 0.37 and 0.11 for production workers and management staff respectively. This is significantly high and statistically significant. Consistent to our previous models, ratio of proprietors is not significant here. On the individual industry level, production workers are significant in 11 out of 12 cases, whereas management staff is significant for5of them.

Model 7 shows overall elasticity of TFP is recorded as 0.15 and 0.26 for production workers and management staff respectively. This is statistically significant. Proprietors are not significant here. Out of 11 industries, the elasticity for production workers was significant for 8 cases. The elasticity for management staff and proprietors was significant for 6 industries.

\subsection{Conclusion and Policy Suggestions}

The importance of production workers is widely acknowledged. With respect to India where many industries are dominated by large family owned enterprises, it is also important to evaluate proprietors' role as well. This study investigated the impact of production workers, management staff and proprietors on TFP, output and labor productivity for 11 industries aggregated for 20 major states of India. It leveraged ASI database that helped us to test the effects for the latest period, 1998-2011. For estimation purpose, the paper used latest econometric techniques panel cointegration and FMOLS that deals with widely known non-stationary and endogeneity issues in panel data.

Firstly, the study computes TFP using fixed effects and random effects model for sample industries. The results indicate that TFPs of the industries have improved for the period considered. In the subsequent step, the paper estimates the significance of production workers, management staff and proprietors with respect to total employees. The estimation was done using FMOLS with Pedroni's cointegration test. The study estimates 7 different models and concludes that the impact of production workers and management staff on TFP, output and labor productivity is strong and statistically significant. For an instance, an increase of 1 percent of production workers promotes TFP by $0.07-0.09$ percent. Further, this impact is found to be even higher on the industrial output and labor productivity; it is approximately 0.37 percent and 0.15 percent respectively. Similarly for management staff and on overall industry level, an increase of 1 percent of management staff can promote the TFP to $0.8-0.18$ percent. Both the results conclude that the overall India manufacturing sector is highly sensitive to production workers and management staff. It is important to note that externalities of production workers and management staff and proprietors on TFP, output 
and labor productivity are consistently significant across the models. The significance to proprietors is neither consistent nor significant.

The study also presents the industry-wise outcome. Management and proprietors externalities affect different industries in different ways. The TFP of Petroleum product and Chemical industry is most sensitive with respect to production workers, management staff and proprietors However, the analysis fails to establish any impact incurred from the externalities of management staff and proprietors on TFP for Tobacco industry.

Three main implications follow from this analysis. First, when considering recommendations for production workers, management staff and proprietors and their impact to TFP, the heterogeneity of the sample data should be taken into account. Apparently the paper considers 11 manufacturing industries and the results cannot be generalized for other industries. Second, it is worth to carry out the similar analysis on firms' level. This will help to establish micro level views. Third and lastly, management skills and relevant experience need to be kept in check while making recommendations on externalities of management staff with respect to productivity.

On recalling the famous Chinese philosopher, Lao Tzu, who said: the journey of thousand miles begins with one step; I believe with this analysis, researchers can proceed differently on the topic of production workers, supervisory staff and proprietors and their impact to productivity. The findings of this paper provide scope for future studies: 1) Investigating further as why production workers do not have externalities effect on TFP for Tobacco industry 2) What is the ideal proportion of management to total employees for high performing firms? 3) Investigating the externalities effect of production workers, management staff and proprietors on TFP-for traditional and modern industries. 4) Validate the findings of this study across developing economies, developed economies and newly industrialized countries and draw comparisons 5) Investigate whether providing the skills such education, niche knowledge, trainings to production workers have impact on production workers.

\section{Conflicts of Interest}

The authors declare no conflicts of interest regarding the publication of this paper.

\section{References}

[1] Pedroni, P. (1999) Critical Values for Cointegration Tests in Heterogeneous Panels with Multiple Regressors. Oxford Bulletin of Economics and Statistics, 61, 653-670. https://doi.org/10.1111/1468-0084.61.s1.14

[2] Pedroni, P. (2001) Fully Modified OLS for Heterogeneous Cointegrated Panels. In: Nonstationary Panels, Panel Cointegration, and Dynamic Panels, Emerald Group Publishing Limited, 93-130.

[3] Levin, A., Lin, C.F. and Chu, C.S.J. (2002) Unit Root Tests in Panel Data: Asymptotic and Finite-Sample Properties. Journal of econometrics, 108, 1-24. 
https://doi.org/10.1016/S0304-4076(01)00098-7

[4] Kathuria, V., Raj, R.S. and Sen, K. (2013) Productivity Measurement in Indian Manufacturing: A Comparison of Alternative Methods. Journal of Quantitative Economics, 11, 148-179.

[5] Balakrishnan, P. and Pushpangadan, K. (1998) What Do We Know about Productivity Growth in Indian Industry? Economic and Political Weekly, 33, 2241-2246.

[6] Goldar, B. (1986) Productivity Growth in Indian Industry. Allied Publishers, New Delhi.

[7] Goldar, B. and Kumari, A. (2003) Import Liberalization and Productivity Growth in Indian Manufacturing Industries in the 1990s. The Developing Economies, 41, 436-460. https://doi.org/10.1111/j.1746-1049.2003.tb01010.x

[8] Mitra, A., Sharma, C. and Véganzonès-Varoudakis, M.A. (2014) Trade Liberalization, Technology Transfer, and Firms' Productive Performance: The Case of Indian Manufacturing. Journal of Asian Economics, 33, 1-15.

https://doi.org/10.1016/j.asieco.2014.04.001

[9] Sharma, C. and Mishra, R.K. (2015) International Trade and Performance of Firms: Unraveling Export, Import and Productivity Puzzle. The Quarterly Review of Economics and Finance, 57, 61-74. https://doi.org/10.1016/j.qref.2015.02.001

[10] Sharma, C. (2010) Does Productivity Differ in Domestic and Foreign Firms? Evidence from the Indian Machinery Industry. Indian Economic Review, 87-110.

[11] Singh, A.P. (2016) Do Technology Spillovers Accelerate Performance of Firms? Unravelling a Puzzle from Indian Manufacturing Industry. Annals of the University Dunarea de Jos of Galati: Fascicle: XVII, Medicine, 22.

[12] Singh, A.P. (2016) R\&D Spillovers \& Productivity Growth: Evidence from Indian Manufacturing. Indian Journal of Industrial Relations, 51, 563-579.

[13] Gort, M. and Lee, S.H. (2003) Managerial Efficiency, Organizational Capital and Productivity. Center for Economic Studies, Bureau of the Census.

[14] Fernandes, A.M. and Paunov, C. (2008) Foreign Direct Investment in Services and Manufacturing Productivity Growth: Evidence for Chile.

[15] Castellani, D. and Giovannetti, G. (2010) Productivity and the International Firm: Dissecting Heterogeneity. Journal of Economic Policy Reform, 13, 25-42. https://doi.org/10.1080/17487870903546226

[16] Silva, A.C. (2010) Managerial Ability and Capital Flows. Journal of Development Economics, 93, 126-136. https://doi.org/10.1016/j.jdeveco.2009.04.005

[17] Amess, K. and Drake, L. (2003) Executive Remuneration and Firm Performance: Evidence from a Panel of Mutual Organisations. Discussion Papers in Economics.

[18] Simoneti, M. and Gregoric, A. (2004) Managerial Ownership and Corporate Performance in Slovenian Post-Privatisation Period. The European Journal of Comparative Economics, 1, 217.

[19] Sav, G.T. (2012) Productivity, Efficiency, and Managerial Performance Regress and Gains in United States Universities: Data Envelopment Analysis. Advances in Management and Applied Economics, 2, 13.

[20] Ilmakunnas, P., Maliranta, M. and Vainiomäki, J. (2004) The Roles of Employer and Employee Characteristics for Plant Productivity. Journal of Productivity Analysis, 21, 249-276. https://doi.org/10.1023/B:PROD.0000022093.59352.5e

[21] Sharma, C. and Mishra, R.K. (2012) Export Participation and Productivity Performance of Firms in the Indian Transport Manufacturing. Journal of Manufacturing 
Technology Management, 23, 351-369. https://doi.org/10.1108/17410381211217416

[22] Baltagi, B.H., Egger, P.H. and Kesina, M. (2016) Firm-Level Productivity Spillovers in China's Chemical Industry: A Spatial Hausman-Taylor Approach. Journal of Ap plied Econometrics, 31, 214-248. https://doi.org/10.1002/jae.2460

[23] Unel, B. (2010) Analyzing Skilled and Unskilled Labor Efficiencies in the US. Journal of Macroeconomics, 32, 957-967. https://doi.org/10.1016/j.jmacro.2010.06.002

[24] Alder, S.D. (2016) In the Wrong Hands: Complementarities, Resource Allocation, and TFP. American Economic Journal: Macroeconomics, 8, 199-241. https://doi.org/10.1257/mac.20120257

[25] Curcio, R. (1994) The Effect of Managerial Ownership of Shares and Voting Concentration on Performance (No. dp0185). Centre for Economic Performance, LSE.

[26] Kahn, J.A. and Lim, J.S. (1998) Skilled Labor-Augmenting Technical Progress in US Manufacturing. The Quarterly Journal of Economics, 113, 1281-1308. https://doi.org/10.1162/003355398555810

[27] Majumdar, R. and Bala Subrahmanya, M.H. (2010) Firm Specific Management Decisions on Total Factor Productivity Growth in Indian Electronics Industry during Liberalisation. International Journal of Economic Policy in Emerging Economies, 3, 272-294. https://doi.org/10.1504/IJEPEE.2010.035182

[28] Feyrer, J. (2011) The US Productivity Slowdown, the Baby Boom, and Management Quality. Journal of Population Economics, 24, 267-284.

https://doi.org/10.1007/s00148-009-0294-Z

[29] Sharma, S. and Singh, N. (2013) Information Technology and Productivity in Indian Manufacturing. Shekhar Shah Barry Bosworth Arvind Panagariya, 189.

[30] Bloom, N., Sadun, R. and Van Reenen, J. (2013) Management as a Technology. Research Paper, Stanford University, Stanford.

[31] Krishna, K.L. and Kapila, U. (2009) Readings in Indian Agriculture and Industry. Academic Foundation.

[32] Goldar, B. (2000) Productivity Growth in Indian Manufacturing in the 1980s and 1990s. Institute of Economic Growth, New Delhi.

[33] Singh, A.P. (2017) Keeping It Simple: Comparative Analysis of TFP across Manufacturing Industries and Major States of India. Theoretical Economics Letters, 7, 1821. https://doi.org/10.4236/tel.2017.76124 